\title{
College, public libraries jointly seek funding
}

Mantor Library, of the University of Maine at Farmington (UMF) and the Farmington Public Library are in the last phase of a successful $\$ 1.5$ million joint capital campaign. The campaign, begun in March 1995, has only $\$ 250,000$ more to go before it ends in June 1997. Mantor Library is using its share of the money to replace the library's HVAC system, renovate public and staff space, buy furniture, create an electronic classroom, and replace old technology with state-of-the-art equipment. Farmington Public Library is using its share of the funding to reallocate space throughout its 100-year-old building, renovate the first floor, buy technology, and build a first floor addition.

One of the goals of the campaign, besides fundraising, has been to look at areas of cooperation between the two libraries, which stand just a football field's length apart. Some cooperative collection development, especially in the area of current literary fiction. will be possible. The public library allows UMF students to check out materials for free, while town residents have access to all of the re-

The enhancement allows researchers to electronically transmit the text of articles or citations to any valid e-mail address and frees them from reliances on printed documents and the availability of a printer.

\section{Winner of the ACRL/Blackwell's Student Paper Award announced}

To encourage leadership in research, ACRL and Blackwell's offered a $\$ 350$ cash prize award and free conference registration for a student whose research paper was selected for presentation at the ACRL 8th National Conference in April. The Contributed Papers Committee is pleased to announce Ethelene Whitmire of the University of Michigan is the winner of this award. Whitmire's paper, "The Campus En-

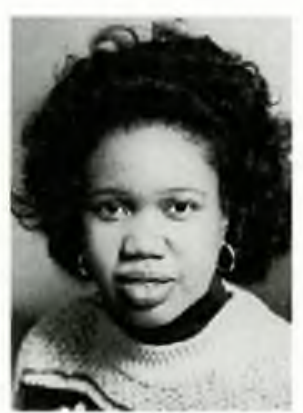

Ethelene Whitmire vironment for African-American and White Students: Impact on Academic Library Experience," sources available through the college library for a small fee. The university will work closely with local educators to provide training in information literacy to teachers and older students in the new electronic classroom, scheduled to open this month.

"The capital campaign ensures the best possible library resources for our region," said Theodora J. Kalikow, president of UMF.

Funding has come from a variety of sources. Locally, a pool of volunteers, called solicitors, has ventured into the communities served by both libraries and raised hundreds of thousands of dollars in three-year pledges, as well as pulling in larger donations from local businesses and individuals. Student organizations have raised $\$ 10,000$ while the college alumni association's request that members give to the capital campaign and to the annual fund has been well received. Major grant support has been provided by the Kresge Foundation, Bingham Betterment Fund, Stephen and Tabitha King Foundation, and Davis Family Foundation.-Frank Roberts, University of Maine at Farmington

will be presented at the conference in Nashville on Saturday, April 13, 2:00-3:00 p.m. The paper describes a research project which analyzed campus influences such as interactions with peers, faculty, and administrators on academic library experiences. Whitmire is a doctoral student studying higher education. She received her MLS from Rutgers in 1993.

\section{Foundation Center launches Web Electronic Reference Desk}

The Foundation Center has launched an Electronic Reference Desk at its Web site, on which a librarian is available to answer questions submitted via e-mail about foundations, nonprofit resources, corporate giving, and the best use of the center's services and resources. Currently, the Electronic Reference Desk has three parts: responses to frequently asked questions (FAQs), the Online Librarian, and a directory of links to other nonprofit sites of interest. The FAQs include responses to common questions such as "Where do I begin my foundation/grants research?" and "How do I find out about grants for my subject area or field of interest?" 